\author{
Anna DYHDALEWICZ, PhD \\ Faculty of Management and Production Engineering, Bialystok University of Technology \\ e-mail: a.dyhdalewicz@pb.edu.pl \\ ORCID: 0000-0001-6605-961X
}

DOI: $10.15290 /$ oes.2018.04.94.02

\title{
ORIENTATION AT RESEARCH AND DEVELOPMENT ACTIVITY FROM THE PERSPECTIVE OF THE ACCOUNTING INFORMATION SYSTEM
}

\begin{abstract}
Summary
Goal - The aim of the paper is to identify research and development in the accounting information system, with particular emphasis laid on the role of the management accounting subsystem in creating information for external reporting purposes.

Research methodology - In order to achieve the goal, a method of scientific description was used, consisting in the analysis of the subject literature in the field of management and accounting, while using inductive reasoning and comparative analysis of selected regulations of the balance sheet law.

Score - The use of the accounting information potential in the area of research and development requires the integration of information in the accounting information system so that the created information will be useful both for management and for the needs of various external stakeholders of the entity. Many methods in the field of management accounting are characterized by the focus on research and development activities. On the basis of the information focused on management needs enterprises can distinguish the components of the innovation process, separate the costs of research works from the costs of development works, document the development of economic benefits in the future, differently recognize the costs associated with them in the financial statements and make balance sheet valuation of the development costs.

Originality/value - The paper is of conceptual character, it presents the contribution to the discussion on accounting convergence in the area of research and development. As a consequence, this process may contribute to the implementation and development of management accounting methods for managing innovative projects in enterprises and improving the quality of information presented in financial statements.
\end{abstract}

Key words: research and development activity, cost of research and development works, accounting

JEL Classification: M41, O32

\section{Introduction}

Accounting is the enterprise's information system, the aim of which is to collect, process and present financial and non-financial information on its activity to various stakeholders. It is universally believed that accounting occurs in the double role [Micherda, 2012, pp. 18-19]. It constitutes: 
- an important source of retrospective information on an economic entity that is addressed at external stakeholders,

- a source of prospective information supporting the decision-making process for enterprise managers. The basic functions of management accounting include active decision-making instrumental functions.

Research and development activity serves as the example of the accounting sphere where the rules of record-keeping and presentation of the general purpose and management information complement one another. It is particularly important while making decisions concerning the implementation development works on an industrial scale and while preparing the source documentation confirming the possibility of successful conclusion of these works and the conditions of activating the outlays.

The main purpose of the paper is to identify the research and development activity in the accounting information system, with particular focus on the role of the management accounting subsystem for creating information for the purposes of external reporting. The achievement of the main purpose required:

1. the presentation of the essence and scope of research and development works,

2. the elaboration of the model of presenting the outlays made on the research and development activity in the accounting information system,

3. the identification of the key concepts and instruments of management accounting that facilitate the management of research and development activity. Additionally, they guarantee the creation and presentation of credible financial and non-financial information in terms of the requirements of the balance sheet low and the application of the information for the realization of needs of particular external stakeholders of a certain economic entity.

Taking into consideration the scope and essence of the research problem the following research thesis has been formulated: The application of the information potential in the sphere of research and development activity requires the integration of information in the information accounting system so that the created information proved useful for both management and for the needs of various external stakeholders of the entity.

The realization of the purpose requires the application of the method of scientific description connected with the analysis of the subject literature while using the inductive inference and the presentation of selected regulations of the balance law: The Polish Accounting Act (PAA) and the International Accounting Standard No. 38 "Intangible assets" (IAS 38). 


\section{The essence and scope of research and development works}

Economic units more and more frequently lay emphasis on innovations, which contributes to the increasing involvement in the research and development activity and to the allocation of relatively large financial resources on this activity. ${ }^{1}$ According to the OECD definition, the research and development activity is a creative activity that is undertaken in a systematic way in order to increase the resources of knowledge and that comprises scientific research and development works and uses the resources of knowledge for creating new solutions [Świadek, 2017, p. 77]. As the result of research and development works there is created a new situation connected with the formation of a new and improved product (product innovations) as well as with the process of its formation (process innovations) [Knosala et al., 2014, p. 221; Gabrusewicz, 2017, pp. 436-437]. These works are most frequently realized by the enterprise's own research and development department. Additionally, the activities may be realized in cooperation with scientific units and within a network of cooperating enterprises and their R\&D centers with the aim of further usage of the mutual potential.

Owing to its complexity, the research and development activity causes substantial diversification of the works connected with the activity's scope. Taking into consideration the functional criterion there are distinguished the following types of this activity [Szczepaniak, 2016, p. 31]:

- basic research considered as the original research works (experimental or theoretical ones) undertaken in order to gain new knowledge, without orientation at particular application or usage, such as the discovery of new scientific laws and theories, usually conducted by external scientific institutes and universities,

- $\quad$ applied research that attempts to use general scientific theories and laws in concrete and practical situations; it is conducted by research institutes as well as by research and development departments being in the structures of the enterprises,

- development works that are conducted in a systematic way and are based on the knowledge gained as the result of the research activity, are closely connected with the elaboration of new or improved technologies, the prototype of a new product, its testing, preparation of technical documentation, the elaboration of the first model of a ready product; the direct result may be patent applications.

According to S. Rokita there is still no single approach to the classification of works in the research and development activity. Presently in this activity the most frequently isolated research is of basic, applied and development type. This division

1 The outlays on research and development works are part of the outlays made on innovative activity, whereas innovations comprise a number of activities going far beyond a typical research and development activity and being realized within the frameworks of implementation works as well as future commercialization of a new product or technology [Świadek, 2017, p. 72]. 
determines the rules of recognizing the costs incurred on the research and development activity within financial accounting [Rokita, 2014, pp. 202-203]. Table 1 presents the basic characteristics of research works and development works that have impact on the analysis of the interrelated costs from the perspective of the balance sheet low.

\section{TABLE 1}

The comparison of research works and development works

\begin{tabular}{|l|l|l|}
\hline \multicolumn{1}{|c|}{ Factors } & \multicolumn{1}{|c|}{$\begin{array}{c}\text { The characteristic of } \\
\text { research works }\end{array}$} & \multicolumn{1}{c|}{$\begin{array}{c}\text { The characteristic of } \\
\text { development works }\end{array}$} \\
\hline The status of the idea & $\begin{array}{l}\text { experimental, theoretical, early, } \\
\text { simple as regards change }\end{array}$ & $\begin{array}{l}\text { targeted at practical application, } \\
\text { harder in terms of change }\end{array}$ \\
\hline Result & $\begin{array}{l}\text { new knowledge, discovery of } \\
\text { something new }\end{array}$ & $\begin{array}{l}\text { new or considerably improved } \\
\text { product, technology }\end{array}$ \\
\hline Time horizon & $\begin{array}{l}\text { well ahead, objective - future } \\
\text { generations of products }\end{array}$ & $\begin{array}{l}\text { project of shorter time horizon } \\
\text { and shorter deadline }\end{array}$ \\
\hline $\begin{array}{l}\text { Future economic } \\
\text { benefits }\end{array}$ & effects - difficult to predict & larger probability of proving \\
\hline
\end{tabular}

Source: own elaboration on the basis of: [Carlsson-Wall, Kraus, 2015, p. 185].

\section{The costs of research and development from the perspective of the accounting information system}

Research and development works are connected with making considerable outlays and are connected with high risk. The return of financial outlays will be possible only in the future, but there is a chance of failure and it is difficult to specify the moment of implementing the effects of conducted works. Owing to this fact the management of research and development activity is becoming more and more important. Of major importance is the selection of proper instruments that will enable planning and management of the achievements in this sphere while using various structures of data, controlling the verified and not implemented results of R\&D projects and assessing the implemented ones. Enterprises invest in R\&D activity mainly in order to guarantee the company's development and the increase its profitability [Grabińska, Grabiński, 2018, p. 44].

International regulations of accounting require the division of tasks into the stage of research works and development works [Markarian et al., 2008, pp. 247-248; Gong, Wang, 2016, p. 51; Waegenaere et al., 2017, p. 1523]. In the Polish Accounting Act as the component of intangible assets and legal assets into consideration are taken solely the costs of completed development works conducted by the unit for its own needs and incurred before starting production or application of the technology. However, PAA and national accounting standards do not specify the very essence of research and development works [Kabalski, 2014, p. 19]. Therefore, it is necessary 
to adopt those solutions that are consistent with IFRS /IAS. According to IAS 38 the non-material assets, i.e. research works, constitute the innovative and planned search for solutions in order to gain and acquire new scientific and technical knowledge. Meanwhile development works constitute a practical application of research discoveries in planning and designing the production of new or considerably improved products and technological processes that take place before starting the serial production and application [MSR 38, 2016, pp. 1369-1370].

Both PAA and IAS 38 allow only for the possibility of capitalizing the outlays made in the stage of development works after certain conditions are met (see chart 1). The requirements point at credible assigning value, the necessity to prove the future economic benefits (e.g. the existence of a market for new products), the availability of funds, technical background and the individual's capability of completing development works and their later commercialization. As the result, the balance includes the element of assets that may be identified and evaluated: the costs of completed development works. The outlays made on research works of the undertaking conducted by enterprises are always included in the costs of operational activity in the moment when they are incurred. As the result of research works there is not formed any component of assets that meets the criteria of intangible assets.

In the functional structure of accounting (apart from financial accounting) one may isolate also tax accounting. The balance law and tax law are independent and autonomous to one another, but the relationships between these categories of law are obvious. The most important motivators of the development of research and development works include the possibility of acquiring subsidies and obtaining a tax relief [Giedroyć, 2018, p. 157]. The tendency to reduce the tax rate from the profit of enterprises is an important argument in favor of pro-innovation activities and the enterprises' capability of financing R\&D activity on their own.

Polish legislator created the incentive to undertake R\&D activity by offering preferential tax solutions. It is the so-called relief on research and development which functions both in the personal income tax and in corporation income tax ${ }^{2}$. It enables a businessman not only to include the outlays on $\mathrm{R} \& \mathrm{D}$ activity into the general catalogue of the costs of obtaining incomes (referred to as eligible costs), but it is also possible for businessmen to avail themselves of additional writing the costs off from the tax base. Therefore, there arises the obligation to isolate such costs in accounting books and document the eligibility to the R\&D relief (e.g. enterprises prepare reports from the realization of research and development works including the justification of satisfying the premises of considering the activity as of research and development type). Simultaneously (as regards the usage of EU subsidies for conducting scientific research and development works) it is required to have application documentation including the assumptions of the planned undertaking, ascribe the tasks to the proper stage and its results. Additionally, it is essential to have documentation confirming the incurred outlays connected with the project

2 Further information: [W sparcie driatalności B+R ..., 2018; Sadej, 2018]. 
realization, keep accounting records and achieve the values of declared indicators. The budget of research and development works is the basic instrument of planning resources as well as of controlling and accounting for the costs of research and development works. It ought to integrate information needs for the realization of various purposes of the entity in the sphere of $R \& D$ activity and in order to prove that the requirements of financial reporting have been met.

\section{Research and development works from the perspective of financial accounting}

\section{CHART 1}

\section{Research and development works}
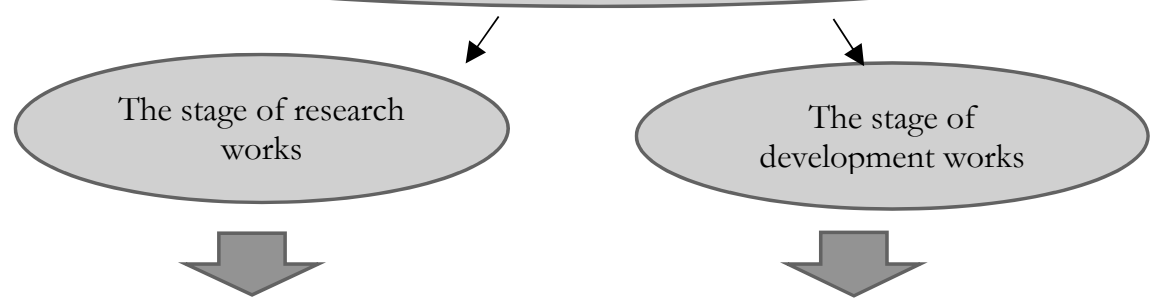

The cost of research works: have impact on the financial result of the period when they were incurred (the costs of operational activity). Presentation in the statement of profits or losses profits and losses

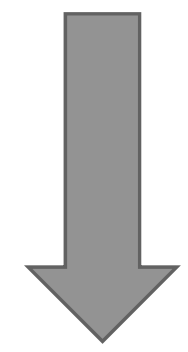

The costs of development works (as long as they meet the conditions specified by the regulations of the balance law):

1. during the realization are shown in the balance assets as:

- Intangible assets (IAS)

- prepayments costs (PAA)

2. are completed:

- $\quad$ with the positive result: capitalized as intangible assets and amortized values,

- $\quad$ with the negative result: writing the costs off in statement of profits and losses

The lack of possibility to separate research works from development works: all the costs are considered as the costs of development works and written off as the financial result of the period when they were incurred. Source of the regulation: IAS 38 and PAA

Source: own elaboration.

The general model of the outlays made on research and development activity in the information accounting system is presented in table 2 . 
TABLE 2

The general model of making outlays on research and development activity in the information accounting system of an enterprise

\begin{tabular}{|c|c|c|}
\hline \multicolumn{3}{|c|}{ The structure of information accounting system of an enterprise: } \\
\hline Financial accounting & Management accounting & Tax accounting \\
\hline \multicolumn{3}{|c|}{ Information addressees: } \\
\hline $\begin{array}{l}\text { mainly external (capital } \\
\text { suppliers, competition, statistic } \\
\text { offices, institutions supporting } \\
\text { and financing R\&D activity) as } \\
\text { well as the unit's management }\end{array}$ & $\begin{array}{l}\text { internal as well as the unit's } \\
\text { surrounding (e.g. business } \\
\text { partners, the institutions } \\
\text { supporting and financing } \\
\text { R\&D activity) }\end{array}$ & $\begin{array}{l}\text { external: State Treasury } \\
\text { and fiscal apparatus as well } \\
\text { as the unit's management }\end{array}$ \\
\hline \multicolumn{3}{|c|}{$\begin{array}{c}\text { The purpose of creating information on the costs of research and development } \\
\text { activity: }\end{array}$} \\
\hline $\begin{array}{l}\text { external tasks: } \\
\text { The requirement to include the } \\
\text { component, make estimation } \\
\text { and disclose certain } \\
\text { information in financial } \\
\text { accounting, preparation of } \\
\text { documentation for the } \\
\text { institutions supporting } R \& D \\
\text { activity, the control of the way } \\
\text { of realizing R\&D project }\end{array}$ & $\begin{array}{l}\text { planning, estimation of the } \\
\text { costs, allocation of resources, } \\
\text { steering and control, } \\
\text { optimizing of the relation } \\
\text { between the costs and effects, } \\
\text { preparation of the application } \\
\text { documentation for the } \\
\text { institutions supporting and } \\
\text { financing R\&D activity }\end{array}$ & $\begin{array}{l}\text { the measurement of } \\
\text { income for taxation and } \\
\text { the specification of the tax } \\
\text { liability, the inclusion of } \\
\text { the expenditures on R\&D } \\
\text { activity as the costs } \\
\text { of gaining incomes and } \\
\text { additional deducting of } \\
\text { costs from the taxation } \\
\text { base }\end{array}$ \\
\hline \multicolumn{3}{|c|}{ Regulation sources: } \\
\hline $\begin{array}{l}\text { national accounting law, EU } \\
\text { accounting directives, IAS/ } \\
\text { IFRS, regulations of the } \\
\text { institutions supporting and } \\
\text { financing innovative activity, } \\
\text { recommendations regarding } \\
\text { statistic research }\end{array}$ & $\begin{array}{l}\text { internal regulations of the } \\
\text { unit's management, } \\
\text { regulations of the institutions } \\
\text { supporting and financing } \\
\text { R\&D activity }\end{array}$ & $\begin{array}{l}\text { tax law: act on personal } \\
\text { income tax (PIT) and } \\
\text { corporation tax (CIT), } \\
\text { other legal acts related to } \\
\text { supporting innovations }\end{array}$ \\
\hline \multicolumn{3}{|c|}{ Definition of $R \& D$ activity and the interrelated costs: } \\
\hline $\begin{array}{l}\text { definitions of research and } \\
\text { development works included in } \\
\text { IAS } 38 \text { Intangible assets, } \\
\text { PAA: specification of condi- } \\
\text { tions for recognizing the costs } \\
\text { of completed development } \\
\text { works as the element of assets } \\
\text { formulated in legal assets and } \\
\text { legal values (according to IAS } \\
\text { in intangible assets) }\end{array}$ & $\begin{array}{l}\text { research and development } \\
\text { works as one of the stages } \\
\text { of the innovative process, } \\
\text { definition depending on the } \\
\text { purposes and requirements } \\
\text { of the unit's management } \\
\text { andsurrounding }\end{array}$ & $\begin{array}{l}\text { changeable tax preferences } \\
\text { depending on the state } \\
\text { policy, definition of R\&D } \\
\text { activity, the scope of } \\
\text { eligible costs in accordance } \\
\text { with the act on PIT and } \\
\text { CIT }\end{array}$ \\
\hline \multicolumn{3}{|c|}{ Features of information: } \\
\hline $\begin{array}{l}\text { credibility and reliability of data, } \\
\text { close periodization, valuable } \\
\text { information ex post and ex ante }\end{array}$ & $\begin{array}{l}\text { orientation at the essence and } \\
\text { timeliness, financial and non- } \\
\text { financial information } e x \text { ante }\end{array}$ & $\begin{array}{l}\text { credibility and reliability of } \\
\text { data, valuable information } \\
\text { expost, close periodization }\end{array}$ \\
\hline
\end{tabular}




\begin{tabular}{|c|c|c|}
\hline \multicolumn{3}{|c|}{ The structure of information accounting system of an enterprise: } \\
\hline Financial accounting & Management accounting & Tax accounting \\
\hline $\begin{array}{l}\text { depending on the needs of } \\
\text { stakeholders }\end{array}$ & $\begin{array}{l}\text { and expost., multi-period } \\
\text { character }\end{array}$ & \\
\hline \multicolumn{3}{|c|}{ Principles of valuation: } \\
\hline $\begin{array}{l}\text { the principle of historical cost } \\
\text { as well as valuation in fail value } \\
\text { value }\end{array}$ & $\begin{array}{l}\text { in general based on } \\
\text { prospective data }\end{array}$ & $\begin{array}{l}\text { the principle of historical } \\
\text { cost }\end{array}$ \\
\hline \multicolumn{3}{|c|}{ The classification of the costs of conducted innovative activity: } \\
\hline $\begin{array}{l}\text { the costs of research works, the } \\
\text { costs of development works, } \\
\text { eligible costs for } \\
\text { reimbursement and non-eligible } \\
\text { costs }\end{array}$ & $\begin{array}{l}\text { 1) owing to the object of } \\
\text { activities; 2) in accordance } \\
\text { with the stages of realizing } \\
\text { research and development } \\
\text { works; } 3 \text { ) in the cross-section } \\
\text { of direct and indirect costs; } \\
\text { 4) in accordance with the } \\
\text { types of the resources being } \\
\text { used 5) in the cross-section of } \\
\text { activities within the stages of } \\
\text { the realized R\&D project; } 6) \\
\text { eligible and non-eligible costs }\end{array}$ & $\begin{array}{l}\text { the costs of obtaining } \\
\text { incomes (eligible costs), the } \\
\text { possibility of whiting off } \\
\text { expenditures from the } \\
\text { taxation base }\end{array}$ \\
\hline \multicolumn{3}{|c|}{ The type of control: } \\
\hline $\begin{array}{l}\text { the analysis of books by } \\
\text { statutory auditors, the internal } \\
\text { control of the processes' } \\
\text { regularity, the control of } \\
\text { financing institutions }\end{array}$ & $\begin{array}{l}\text { management control of the } \\
\text { effectiveness and efficiency of } \\
\text { achievements in terms of the } \\
\text { realized research and } \\
\text { development works }\end{array}$ & $\begin{array}{l}\text { the analysis of tax } \\
\text { obligations by inland } \\
\text { revenues }\end{array}$ \\
\hline \multicolumn{3}{|c|}{ Basic financial reports: } \\
\hline $\begin{array}{l}\text { disclosed financial report, } \\
\text { reports in accordance with the } \\
\text { requirements of the financing } \\
\text { institutions, statistic surveys }\end{array}$ & $\begin{array}{l}\text { internal reports: in accordance } \\
\text { with the types of realized } \\
\text { R\&D projects, in accordance } \\
\text { with the requirements of } \\
\text { institutions financing the } \\
\text { projects }\end{array}$ & $\begin{array}{l}\text { tax declarations, budgets of } \\
\text { tax obligations }\end{array}$ \\
\hline
\end{tabular}

Source: own elaboration.

Table 2 shows that the differences between the analyzed subsystems are clear, but different information needs of stakeholders cause partial integration of historical and planning data on an enterprise's scale as well as blurring the borders between the created subsystems. On the one hand, financial accounting considers research and development works in the categories of the outlays made on them and the measurable effects. The purpose is to specify the uniform way of presenting, evaluating the value in the moment it is taken in the balance and of disclosing certain information in additional data and explanations within the frameworks specified by the law. While presenting the costs of research and development works 
in financial reports one takes into consideration the possibility of using their effects in practice and the degree of the certainty regarding the achievement of future economic benefits by them. However, enterprises encounter a problem with clear classification of incurred costs in the isolated stages (also for tax purposes). Management accounting has instruments that enable not only the support of decisionmaking processes. The information created for management purposes become the source of information for financial reports, preparing documentation in accordance with the needs of the institutions financing $\mathrm{R} \& \mathrm{D}$ activity as well for the control and evaluation of the current activity in this sphere. In the subject literature this process means the convergence between management accounting and financial accounting (state) or the creation of convergence between these areas (process) [Sobańska, 2003, p. 248; Kabalski, Zarzycka, 2018, p. 84]. Convergence in the sphere of research and development works means the combination of the retrospective and prospective system of financial information that will serve both the purposes connected with making decisions and reporting. In order to meet these demands, in the accounting system there must occur firstly the collection of data and its processing in accordance with specific rules. Owing to the changing legal solutions it is impossible to achieve full convergence of various information needs of external stakeholders and confidentiality of information. However, it is crucial to specify the possibility of communicating information between these subsystems.

\section{Selected methods of management accounting oriented at the research and development activity}

In the management of research and development processes resulting in the formation of a new product and development of technologies the challenge is not connected with simple distribution of resources in the system, but the settlement of how to use them effectively [Tidd, Bessant, 2011, p. 132]. Many methods from the area of management accounting are oriented at research and development activity [Dyhdalewicz, 2018, pp. 509-510]. The first group of methods comprises methods supporting solely the management of the costs of research and development activity (oriented at the processes of strategic management) in either long-term or shortterm perspective (serving operational aims). This group comprises the account of innovation costs, which takes into account the grouping of costs within basic and applied research as well as development works, the account of the costs of the product's life cycle, the account of the costs of activities, the budgeting of costs in the research and development activity. The second group includes methods that include data on the revenues, costs and effectiveness of the result measured using the growing account, such as: life cycle costing and profitability and target costing. Importantly, apart from the outlays on the realization of a certain undertaking these methods present the enterprise's ability to realize economic benefits obtained by means of organization. Another group includes the methods combining the most important aspects of the enterprise's activity in integrated models of achievements 
that are formulated on the basis of the organization's mission and strategy. As the example may serve balanced scorecards (BSC).

The advantage of the aforementioned methods is the support of the processes of the management of research and development activity. During the analysis of their assumptions it is possible to identify the areas where information from this subsystem becomes indispensable for the purposes of financial reporting and the needs of various groups of stakeholders. On the basis of information supporting management an enterprises may isolate the components of research and development activity, separate the costs of research works from the costs of development works and differently consider the costs connected with them in the financial report. Hence stakeholders obtain information on the effects of the conducted R\&D activity. Simultaneously they constitute the source of useful information that complements the financial report. The report on activity ought to present the most important achievements and characteristics of conducted research and development works (e.g. their purpose, course, hazards, deadline, results, costs, realization manner and the financing source) [Dyczkowska, 2016, p. 132]. The support of decision-making processes of external stakeholders by the system of financial and non-financial information resulted from declared needs and at the same time proves that it is possible to use information systems supporting the management process for the needs of external reporting [Piotrowska, 2016, p. 214].

With regard to both IAS 38 and PAA the outlays on research works ought to be presented in the perspective of the costs in the moment they are incurred owing to the uncertainty of obtaining future benefits for the unit. It leads to limited possibility of presenting information on the internally generated non-material resources which decide upon the innovative character of the entity [Michalczuk, 2013, p. 177]. The costs of development works may be activated when certain conditions have been met. One of them is the credible specification of the costs incurred on creating the component of non-material assets. The key role in this aspect is played by the cost accounting of an enterprise. Additionally, it is necessary to prove the accessibility of technical and financial resources that are necessary to complete and commercialize development works, i.e. the way in which the component of intangible assets will probably create future economic benefits (e.g. the existence of a market for new products). After the first check-up balance sheet evaluation requires also checking whether the capitalization criteria have been met, i.e. the confirmation that the component still has economic benefits, whereas in case of the loss of their value the deduction of the loss should take place. From the point of view of estimating the period of using and quantifying the future economic benefits what proves particularly useful is the life cycle costing [Kabalski, 2014, p. 106], as well as of target costing [Mielcarek, 2018, pp. 83-84]. IAS 38 isolates the life cycle as one of the factors that determine the period of using the component of assets. The calculation of target costs is concentrated on the impact of decisions made in the preproduction stage and at the same time is the instrument that measures profitability and financial success over a long period. This method implies the measurement of future economic benefits from the completed development works and spread them 
in time. The cost budget in research and development activity constitutes the basic instrument of planning resources in accordance with the types of performed works. Later on it may constitute the basis of the qualification of truly made outlays for research works or development works and the analytical record-keeping of the costs in accordance with the requirements of various stakeholders (e.g. institutions offering subsidies or the control of using tax reliefs), controlling and accounting for the realized works.

To sum up, it needs emphasizing that in the sphere of research and development activity the challenges to the modern accounting include the convergence of financial and management accounting. On the basis of the past reflections it is possible to identify the scope of penetration of both prospective and useful information generated using the methods of management accounting for financial reports or planning and reporting the expenditures on R\&D activity for the needs of external addressees.

\section{Conclusions}

The problem regarding the perspective of research and development activity is one of more difficult areas of accounting. The paper has conceptual character, presents the contribution to the discussion on the convergence of accounting in the sphere of research and development works. As the consequence this process may contribute to the implementation and development of methods of management accounting for the purposes of management of research and development projects in enterprises and to the improvement of the quality of information on them that is presented in financial reports.

The conditions of the convergence of accounting in the sphere of research and development works include:

1. the selection of stakeholders of information on research and development activity and their information needs,

2. the selection of adequate instruments oriented at the measurement, analysis and reporting information supporting management and confirming the effect of R\&D project's conclusion,

3. current record-keeping taking into consideration the grouping of information used for management purposes and distribution of management information for including and disclosing information in reporting for external purposes.

The exchange of information between the subsystems of accounting obviously constitutes the challenge for both science and practice of accounting. The common feature of the issues of this problem is the potential possibility of using the budgeting of the costs of research and development works. According to the Author the basic limitation of financial accounting is the concentration on the costs of development works. Less attention is devoted to the earlier stage of this activity is is decisive and crucial for the success of the research and development project. The basic assumption of conducting research works is the search for the solutions 
enabling the application of new scientific and technical knowledge in the enterprise's practice and achievement of benefits from them. The realization of these works not only contributes to starting the subsequent stage of realizing the innovative project development works, but also has impact on the entity's competitiveness on the market. The information gap in this aspect is filled by management accounting which offers methods emphasizing the importance of both research works and development works. Thus it enables the realization of tax obligations and the obligations connected with using EU subsidies on financing R\&D activity.

\section{References}

Carlsson-Wall M., Kraus K., 2015, Opening the black box of the role of accounting practices in the furzy front-end of product innovation, "Industrial Marketing Management", no. 45 .

Dyczkowska J., 2016, Ujawnienia pozafinansowe dotyczqce działan badawczo-rozwojowych w sprawozdaniach zarzqdów spótek biotechnologicznych, „Studia Ekonomiczne. Zeszyty Naukowe Uniwersytetu Ekonomicznego w Katowicach”, nr 284.

Dyhdalewicz A. 2018, Managerial aspects of innovations costs - Case Study, [in:] Economic and Social Development: 27th International Scientific Conference on Economic and Social Development: Book of Proceedings, Varazdin Development and Entrepreneurship Agency, University North, University of Warsaw, Rome.

Gabrusewicz W., 2017, Koszty prac rozwojowych w dokonaniach przedsiebiorstw, [w:] Finansyzacja $i$ jej wplyw na globalny rozwój sprawozdawczości finansowej. Wybrane prace z dorobku naukowego Katedry Rachunkowości Uniwersytetu Ekonomicznego w Poznaniu w latach 2007-2017, Kamela-Sowińska A. (red.), Uniwersytet Ekonomiczny w Poznaniu, Poznań.

Giedroyć M., 2018, Uznawanie kosztów badań i rožwoju w rachunkowości, „Prace Naukowe Uniwersytetu Ekonomicznego we Wrocławiu”, nr 503, Współczesne problemy $w$ nauce, dydaktyce $i$ praktyce rachunkowości, Wydawnictwo Uniwersytetu Ekonomicznego we Wrocławiu, Wrocław.

Gong J.J., Wang S.I-L., 2016, Changes in the value relevance of research and development expenses after IFRS adoption, Advances in Accounting, Incorporating, Advances in International Accounting, vol. 35, DOI: 10.1016/j.adiac.2016.05.002.

Grabińska B., Grabiński K., 2018, Wplyw nakładów na badania i rozwój na rentowność przedsiębiorstw, „Zeszyty Teoretyczne Rachunkowości”, t. 96(152), DOI: 10.5604/ 01.30001.0011.6169.

Kabalski P., 2014, MSSF a ustawa o rachunkowosci (6). Aktywa niematerialne, „Rachunkowosć", nr 7 .

Kabalski P., Zarzycka E., 2018, Konwergencja rachunkowości finansowej $i$ rachunkowości zarzqdczej $w$ Polsce $w$ swietle badań ankietowych, „Zeszyty Teoretyczne Rachunkowości”, t. 96(152), DOI: 10.5604/01.30001.0011.6171.

Knosala R., Boratyńska-Sala A., Jurczyk-Bunkowska M., Moczała A., 2014, Zarzqdzanie innowacjami, PWE, Warszawa. 
Markarian G., Pozza L., Prencipe A., 2008, Capitalization of R\&D costs and earnings management: Evidence from Italian listed companies, "The International Journal of Accounting", vol. 43(3).

Michalczuk G., 2013, Zasoby niematerialne jako cąynnik wartości przedsiębiorstwa. Luka informacyjna sprawozdawczości finansowej, Wydawnictwo Uniwersytetu w Białymstoku, Białystok.

Micherda B., 2012, Wybrane aspekty ewoluci rachunkowości, [w:] Kierunki ewoluci sprawozdawnçości i rewizji finansowej, Micherda B. (red.), Difin, Warszawa.

Mielcarek J., 2018, Ocena uniwersalności target costing jako metody zarzadzania innowacjami, [w:] Innowacyjnośc polskiej gospodarki: mybrane aspekty, Opolski K., Górski J. (red.), Wydział Nauk Ekonomicznych Uniwersytetu Warszawskiego, Warszawa.

MSR: Miedzynarodowy Standard Rachunkowości 38 Aktywa niematerialne, 2016, [w:] Miedzynarodowe Standardy Sprawozdawczości Finansowej. Cžsśc A. Zatożenia koncepcyjne i wymogi, IFRS, SKwP, Londyn, Warszawa.

Piotrowska K., 2016, Wiarygodność sprawozdania zৃintegrowanego jako źródta informacji o driatalności innowacyjnej, „Studia Oeconomica Posnaniensia“, vol. 4, no. 11, DOI: 10.18559/SOEP.2016.11.15.

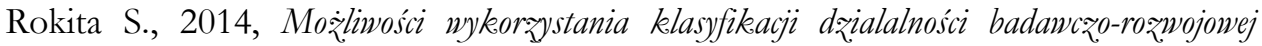
w zarzadzaniu przedsiebiorstwem, „Modern Management Review“, vol. XIX, 21(4).

Sadej M., 2018, Ulga na dziatalność badawczৃo-rozwojowa w 2018 r., „Rachunkowość”, nr 3.

Świadek A., 2017, Krajony system innowacji w Polsce, CeDeWu, Warszawa.

Sobańska I., 2003, Wptyw MSR na integracje rachunkowości: racbunkowość finansowa i rachunkowosí zarzadcza, „Zeszyty Teoretyczne Rachunkowości”, nr 13(69).

Szczepaniak P., 2016, Procesy zarzadzania wiedza w projektach badawczo-rozpojowych, „Studia Ekonomiczne. Zeszyty Naukowe Uniwersytetu Ekonomicznego w Katowicach", nr 278.

Tidd J., Bessant J., 2011, Zarzadzanie innowacjami. Integracja zmian technologicznych, rynkowych i organizacyjnych, Oficyna a Walters Kluwer business, Warszawa.

Ustawa z 29 września 1994 o rachunkowości, Dz.U. z 2018 r. poz. 395.

Waegenaere A., Sansing R.C., Wielhouwer J.L., 2017, Development Cost Capitalization During R\&D Races, “Contemporary Accounting Research”, vol. 34, no. 3.

Wsparcie driatalności B+R $i$ nowych inwestycji, 2018, „Rzeczpospolita Poradnik Prenumeratora", nr 10. 